Beata Edyta Dworakowska

Uniwersytet w Białymstoku

Wydział Filologiczny

Instytut Filologii Wschodniosłowiańskiej

tel. +48857457450

e-mail: beatadworakowska@wp.pl

\title{
Wrotycz, storczyk i wszystkie inne boże zielska w wierszach Jana Twardowskiego i ich rosyjskich przekładach
}

Słowa kluczowe: poezja Jana Twardowskiego, obraz roślin, przekład

\section{Poezja Jana Twardowskiego - uwagi ogólne}

Poezja księdza Jana Twardowskiego jest bardzo popularna wśród rzeszy czytelników w kraju i poza jego granicami. Charakteryzuje się ona prostotą wyrazu, różnorodnością tematyczną i bezpośrednim kontaktem z odbiorcą. Wśród licznych utworów autora znajdują się wiersze poświęcone przyrodzie. Poeta zawsze podkreślał, że świat przyrody ukazuje bogactwo i dobroć Stwórcy. Jest to pogląd oparty na dogmatach wiary chrześcijańskiej. Wiersze księdza Jana przekonują nas do codziennej obserwacji świata, świadomości wagi miejsca, w które wrośliśmy, do refleksji nad zastaną naturą. Jego poezja wyraża pogodną akceptację oraz pieśń chwały na cześć stworzenia i Stwórcy. Świat ukazywany w poszczególnych utworach jest zbiorem rzeczy realnie egzystujących z wielością konkretów.

Ksiądz Twardowski próbował zaprezentować w swoich wierszach całe życie, nie tylko życie ludzi, ale także świat ptaków, zwierząt, roślin ich samotność, radość, uśmiech i zmartwienie [zob. Poeta... 1981, 56-58]. Przyroda w utworach poety jest osobnym bohaterem. Autor przypomina, że świat przyrody nie pozostaje w izolacji od człowieka, wręcz prze- 
ciwnie, jest mu bardzo bliski. Twardowski z miłością traktuje najdrobniejszych przedstawicieli świata fauny i flory, w czym można dopatrywać się postawy franciszkańskiej [por. Karwala 1996, 77]. Twardowski był zakochany w świecie przyrody. Nazywał świat po imieniu, poprzez przedstawianie cudowności świata $\mathrm{w}$ najdrobniejszych szczegółach przekazywał $\mathrm{w}$ swoich wierszach tajemnice istnienia. Twardowski $\mathrm{w}$ swoich utworach przekazał franciszkańską wrażliwość, wiarę w stworzenie i optymizm poznawczy. Jest to poezja pokorna wobec każdego istnienia [por. Sochoń 2007, 44]. Różnorodne elementy świata natury bogato ilustruje poezja księdza Jana, która obejmuje relacje człowieka ze światem roślin, zwierząt a nawet całych systemów przyrodniczych. Obraz roślin został wyłoniony na podstawie tekstów 52 wierszy w jezzyku oryginału i ich odpowiedników w języku przekładu, wyekscerpowanych z materiałów źródłowych [zob. Źródła].

\section{Poetycki obraz roślin jako forma prezentacji świata}

Rośliny pełnią wielorakie funkcje: ozdobną, leczniczą. Stanowią również pożywienie dla ludzi i zwierząt, pomagają w wyrażaniu uczuć. Naturalne a zarazem magiczne właściwości roślin, np. zapach, działanie trujące, wartości odżywcze zapewniają im szczególne miejsce w wierzeniach i obyczajach ludzkich. Są elementem świata stworzonego przez Boga. Stosunek człowieka do przyrody powinien być odwzorowaniem postawy ogrodnika, mądrego zarządcy. Życie każdej rośliny jest obrazem działania Boga.

Przyroda zajmowała w życiu księdza Jana szczególne miejsce. Początkowo poeta uczył się przyrody ze starego zielnika rodzinnego. Miłość do roślin, obudzona za młodu, pozostała w duszy poety przez całe życie. Twardowski często wychodził na łąkę, do lasu, próbując nazywać rośliny po imieniu. Przypatrywał się różnym gatunkom traw, niepozornym kwiatom, cieszył się krzewami i zachwycał potęgą drzew. Idąc dostrzegał wiele szczegółów przyrodniczych. Dla niego nawet chwasty miały swój wdzięk, proporcje, delikatność, oryginalność barwy. Uważny wzrok, węch i dotyk były doskonałymi narzędziami, którymi posługiwał się poeta, a wiedza, którą zdobył i przekazał w wierszach pomaga w odkrywaniu tajemnic przyrody. Dla Twardowskiego „Świat okazał się wielkim, niewyczerpanym herbarium, które można otwierać na przedwiośniu i czytać aż do pierwszych mrozów" [Sulikowski 2007, 85]. Przyroda żyje swoim rytmem, o czym świadczy następstwo kwitnienia roślin, cykle wegetacyjne. Świat roślin jest precyzyjnie zorganizowany, co świadczy o wielkości Stwórcy. 
Rośliny mają bogatą symbolikę, zarówno w Biblii, jak i w literaturze, ludowych wierzeniach i obyczajach. W metaforyce Nowego Testamentu rośliny wiążą się ze wzrostem wewnętrznym i są symbolem życia. W pobożnych legendach wzrastanie roślin, ich pokrywanie się zielenią i kwiatami symbolizuje moc świętych. Rośliny wyobrażają także poszczególnych ludzi, to, co dzieje się we wnętrzu człowieka, są symbolem Dziewicy Maryi [zob. Lurker 1989, 199-201]. Według Władysława Kopalińskiego swoją symbolikę mają nazwy ogólne: drzewo jest m.in. symbolem wzrostu, wielkości, królewskości, piękna, krzyża, życia i śmierci; kwiat - tajemnicy, niewinności, dojrzewania, subtelności, piękna, przemijania; las symbolizuje płodność, pustelnię, tajemnicę; liść- życie, kwitnienie, nadzieję; ogród - raj, szczęście, schronienie; zboże - obfitość, płodność, błogosławieństwo. Badacz podaje także symbolikę konkretnych przedstawicieli poszczególnych gatunków i odmian drzew, kwiatów, krzewów, zbóż, np.: brzoza symbolizuje niewinność, czystość; figa jest symbolem płodności, obfitości; jabłko - życia, nieśmiertelności, wiedzy, niezgody; jesion - majestatu, wspaniałości, potęgi, szlachetności; lilia - niewinności, dziewictwa; mak symbolizuje zapomnienie, ciszę, czystość; orzech - twardość, prawdę; róża - życie, doskonałość, elegancję, mądrość, tajemnicę; topola - wyniosłość, połączenie przeciwieństw, życie, nieśmiertelność; wierzba - tęsknotę, smutek, mądrość [zob. Kopaliński 2006].

W poetyckich obrazach Jana Twardowskiego możemy odnaleźć 95 jednostek opisujących świat flory. Spośród nich 22 jednostki to uogólnienia typu: drzewa, kwiaty, las, liście, taka, pole, rośliny, trawy, zioła, a 73 nazwy określają konkretne rośliny. Najliczniejszą podgrupę stanowią drzewa i krzewy (22 jednostki), np.: kasztan, buk, brzoza, wierzba, akacja, topola, olcha. Poza tym w tekstach możemy odnaleźć 16 nazw różnych owoców i warzyw, np.: jabtko, cebula, orzech, pomidor, szparagi, jeżyny. Stosunkowo dużą grupę stanowią rośliny ozdobne (18 jednostek), np.: róża, lilia, bodziszek, storczyk, siódmaczek; rośliny zielne (8 jednostek), np.: szatwia, dziwaczek, psia trawka, bławatek oraz rośliny pełniące obie te funkcje jednocześnie, czyli ozdobne i lecznicze (9 jednostek), np.: głóg, wrzos, nagietek, jaskótcze ziele, wrotycz. Nazwy roślin wybrane z badanych utworów pozwalają stwierdzić, że dla poety istniała równorzędność gatunków i odmian: wielkie drzewa rosną obok niskich krzewów, szlachetne kwiaty - róże obok skromnych niezapominajek bądź uważanych za chwasty mleczy.

\section{a) Obraz drzew i krzewów}

Na szczególną uwagę zasługują drzewa. One zawsze były objawem życia. Dorothea Forstner pisze, że: „Drzewo (...), ten najdoskonalszy twór świata 
roślinnego, już samo w sobie jest tego rodzaju, że mogło wprawiać pierwotnych ludzi w podziw. Przeczuwali w nim wyraz wyższej mocy. (...) drzewo jest teofanią, obrazem kosmosu, symbolem życia, punktem centralnym świata, alegoria ciągle odradzającej się natury" [1990, 151]. Drzewo, zakorzenione głęboko w ziemi, wyrasta ponad wszystkie inne istoty żywe, co dało początek obrazom drzewa świata, które łączyło niebo z ziemią. W cieniu drzew składano ofiary, okolice rosnących drzew stawały się miejscami świętymi. W Edenie Bóg stworzył drzewo życia i poznania. W Nowym Testamencie drzewa wydające owoce i niewydające ich stanowią metaforę ludzi dobrych i złych. Symbolem drzewa życia jest także Maryja, która wydała na świat owoc - Jezusa Chrystusa. Drzewo krzyża, na którym umarł Syn Boży jest zaś symbolem odrodzenia, zmartwychwstania [zob. Lurker 1989, 48-50]. Także w naszych czasach nie sposób nie podziwiać i nie cenić drzew. Drzewa bezinteresownie dają nam dobro, za które powinniśmy się im odwdzięczyć. Ksiądz Jan podczas spacerów do parków lub wyjazdów na wieś podziwiał szpalery drzew, dotykał i obserwował kwiaty, wdychał aromaty. Swoje spostrzeżenia przekazywał w wierszach, m.in.: brzozy mają trójkątne liście, a liście olchy są okrągłe, akacja pachnie zawsze przed deszczem, owocem leszczyny są orzechy laskowe, drzewa dają cień, buki najlepiej chronią przed upałem, topole nie lubią rosnąć zbyt blisko siebie, grab nadaje się na szpalery, akacja daje biały miód, głóg jest schronieniem dla gajówki, jesion pierwszy traci liście itd., np.:

Tu znowu tak samo i nic się nie zmienia / trójkątne liście brzozy i olchy okrągłe / akacja pachnie jak za czasów Prusa / obowiązkowo bo zawsze przed deszczem / (...) leszczyna rodzi swój orzech laskowy / (...) cień drzewa w samo południe wskazuje na północ / (...) Pan Cogito zdumiony meandrami świata / niech wybaczy wiersze rwane prosto z krzaka (Wiersz $z$ dedykacja, Zaufałem...)

Тут все как было прежде без всяких перемен / листья ольхи округлы березы треугольны / акация тут пахнет как пахла в годы Пруса / и пахнет непременно всегда перед дождем / (...) лещина тут рождает лесной орех (...) тень дерева тут в полдень показывает север / (...) Пан Когито который мир в сложностях постиг / пусть сорванные прямо с куста стихи простит (Стихотворение с посвящением, Н. Астафьева, Польские поэты...)

Szkoda / dla jednej tylko osoby / (...) buków bo najchłodniej przy nich wśród upału (...) (Przyrost ludności, Zaufałem...)

Жалко / для одного человека / (..) буков возле которых в жару хранится прохлада (...) (Прирост населения, О. Басий, Стихи)

Было бы жаль / для одного человека / (...) буков что дают прохладу в зной (...) (Прирост населения, Н. Астафьева, Польские поэты...) 
Przeżyć samotność chociaż jest się razem / nie dziw się że bliski staje się daleki / milczą za gęsto rosnące topole / dwie obok siebie niespokojne rzeki (...) (We dwoje, Zaufałem...)

Быть одиноким и в совместной жизни / не удивляться близких отдаленью / молчат все тополя в рядочке тесном / двух беспокойных рек одно теченье (...) (Вдвоем, А. Нехай, Просьба)

Brzozo nazbyt wieśniacza aby rosnąć w mieście / dyskretny grabie w sam raz na szpalery / jarzębino dla drozdów dzwoniących i szpaków / akacjo z której nie złote tylko białe miody / olcho co jedna masz przy liściach szyszki / głogu co chronisz gajówkę krewniaczkę słowika / jesionie co pierwszy tracisz liście zbliżając nam jesień / Poproście Matkę Bożą abyśmy po śmierci / w każdą wolną sobotę chodzili po lesie / bo niebo nie jest niebem jeśli wyjścia nie ma (Drzewa, Zaufałem...)

Береза слишком дикая чтобы расти в городе / нежный граб что в самый раз на шпалеры / рябина дом родной для звенящих дроздов и скворцов / акация мед с которой не золотой а белый / ольха единственная у кого и листья и шишки / боярышник прячущий славку родственницу соловья / ясень первым теряющий листья приближая к нам осень / попросите Матерь Божию чтобы после смерти / каждый выходной мы по лесу гуляли / ведь небо не в небо коли выхода нету (Деревья, А. Базилевский, Польская поэзия...)

Piękno, majestat i doniosłą rolę drzew w naszym życiu dostrzega także ksiądz Twardowski, gdy pisze: „Jakże tajemnicze jest drzewo. Wyrasta taki kolos i żyje, w niewidzialny sposób czerpiąc powietrze i tlen. Umiera jesienią, aby na wiosnę się odrodzić. Dla mnie drzewo to pamiątka biblijnego raju. (...) Każde drzewo mówi o Bogu" [2007, 62]. Drzewo stanowiło dla poety osobny świat, nawet osobną cywilizację. Wobec wielkości i potęgi drzewa, ciało ludzkie wydaje się nikłe i bezradne. Największe w królestwie roślin, a jednocześnie dyskretne drzewa wspomagają świat człowieka, chroniąc nas przed skutkami naszej niefrasobliwości ekologicznej [zob. Sulikowski 2007, 81-95].

\section{b) Obraz owoców i warzyw}

Kolejną grupę roślin, pojawiających się w poszczególnych wierszach Twardowskiego, stanowią nazwy owoców i warzyw. W tradycji ludowej, owoce są symbolem płodności i życia. W symbolice chrześcijańskiej owoce to cnoty życia wewnętrznego, dzieła człowieka, potomstwo rodzaju ludzkiego, Chrystus [zob. Forstner 1990]. W mowie potocznej oznaczają one rezultat pracy, a także wysiłków duchowych. W znaczeniu przenośnym owocami nazywa się dobre uczynki, dokonywane przez człowieka. Przywołanie owoców 
w badanych utworach ma znaczenie podstawowe. Wiąże się najczęściej ze wspomnieniem dzieciństwa, młodości, domu rodzinnego, matki, dawnych krajobrazów i niezapomnianych smaków. Poeta opisuje ich wygląd, czas rośnięcia, dojrzewania, zastosowanie: czereśnie dojrzewają po maturach, ogórki rosną tylko nocą, cebula jest „krewną” lilii, obierana cebula powoduje płacz, pomidor ma pępek, pietruszka ma działanie moczopędne, np.:

Co nam jeszcze zostało / (...) z pomaturalnych czereśni / (...) z kasztanów spadających (...) (***, Zaufałem...)

Что еще нам осталось / (...) от выпускных черешен / (...) от каштанов летящих в воду (...) (***, А. Нехай, Просьба)

Tu znowu jest tak samo i nic się nie zmienia / (...) ogórki jak wiadomo rosną tylko nocą / (...) święta cebula krewna zdechłej lilii / strip-tease przyzwoity zasłania swym płaczem (...) (Wiersz z dedykacja, Zaufałem...)

Тут все как было прежде без всяких перемен / (...) огурчики известно растут лишь в час ночной (...) а родственница лилий луковица святая / стриптиз вполне приличный прикрывает плачем (...) (Стихотворение с посвящением, Н. Астаф-ева, Польские поэты...)

(...) a tu zwykła matka / (..) moczopędna pietruszka / z selerem sałatka / i bardzo ludzka miłość (...) (Matka, Zaufałem...)

(...) а тут вот мать / (...) и мочегонная пертушка / салат из сельдерея / и очень человечная любовь (...) (Мать, А. Нехай, Просьба)

Tobie (...) pomidor z pępkiem koszyk z maślakami (...) (Więcej, Zaufałem...)

Тебе (...) пузатый помидор корзинка полная маслят (...) (Все более, А. Нехай, Просьба)

Jednocześnie pojawiają się wiersze, w których te obrazy użyte są w sposób przenośny lub wchodzą w skład frazeologizmów. Wykorzystane są w danych zwrotach takie cechy roślin, jak: surowy grzyb jest niejadalny, kwaśne jabłko, np.:

(...) być zbitym na kwaśne jabłko (Wiem, Zaufałem...)

(...) быть избитым до полусмерти (Знаю, А. Базилевский, Стихи)

(...) narzekasz że świat surowy jak grzyb niejadalny / a w świecie stale uśmiech niewidzialny (Nieszczęście nie-nieszczęście, Zaufałem...)

(...) ты говоришь что мир суров как грибы ядовитые / а в мире всегда живет улыбка сокрытая (Несчастье не-несчастье, О. Басий, Стихи) 
Badany materiał różnicuje rośliny przede wszystkim poprzez wyeksponowanie cech związanych z ich budową, wpływem na człowieka i możliwością ich wykorzystania. Uwzględniając to, możemy je podzielić na rośliny ozdobne, zielne i te, które pełnią jednocześnie obie funkcje. Rośliny ozdobne to jednoroczne, dwuletnie lub wieloletnie rośliny, także drzewa i krzewy o dużych walorach dekoracyjnych, np. o pięknych i ciekawych kwiatach, owocach, ulistnieniu, zabarwieniu pędów, pokroju, a także interesujących właściwościach. Funkcję ozdobną pełnią przede wszystkim kwiaty, wykorzystywane do bukietów, wieńców, wiązanek [zob. Piekarczyk 2004, 213, 223]. Kwiaty to zwiastuny wiosny. Podobnie jak człowiek, wykazują one szczególne powiązanie ze światłem i życiem, podlegają prawom ziemskiego przemijania. W metaforyce biblijnej kwiaty obrazują przemijanie wszystkiego, co ziemskie. Ale kwiaty - zwłaszcza ich najpiękniejsze okazy - mogą też kierować ku nadprzyrodzonemu pięknu. Są one ziemskim wyobrażeniem niebieskiej szczęśliwości [zob. Lurker 1989, 106-107]. Dorothea Forstner zauważa, że: „W różnych symbolach pór roku (...) wiosnę wyobrażały kwiaty. Te dzieci światła, otwierające swoje kielichy ku słońcu, są zwiastunami i znakami wiosny, są weselnym strojem budzącej się do życia natury, nadzieja przyszłego owocu, cząstka utraconego raju (...). Każdy kwiat, od najmniejszego do największego, jest w każdej swej cząstce ukształtowany według miar geometrycznych, a jednak nie ma w nim nic skostniałego, nic wymuszonego, tylko wdzięk i urok, zapach i przepych kolorów w nieskończonej różnorodności" [1990, 184]. W utworach Twardowskiego to przede wszystkim kwiaty pełnią funkcję ozdobną, chociaż autor zachwyca się także drzewami, krzewami, o czym była mowa powyżej. Kwiaty przyciągają alchemią barw, pięknym kształtem, magiczną wonią, oryginalnym kwitnieniem. Spośród roślin pełniących rolę dekoracyjną, najczęściej wspominane są w wierszach róża i lilia. Inne rośliny, m.in.: chryzantema, firletka, konwalia, malwa, smótka, stokrotka, tulipan, zawilec wymienione są w analizowanych utworach jednokrotnie. Poeta zwraca szczególną uwagę na budowę kwiatów: róże posiadaja kolce, zawsze ciekawie wyglądają, stokrotka ma czasem nie 100 a 98 płatków, np.:

(...) Piękne są góry i lasy / i róże zawsze ciekawe (...) (***, Zaufałem...)

(...) Прекрасны леса и горы / и розы красой пленяют (...) (***, А. Базилевский, Сделано в Польше)

(...) stokrotka ma czasem płatków dziewięćdziesiąt osiem (...) (Piszę, Zaufałem...)

(...) у маргаритки и девяносто восемь лепестков иногда бывает (...) (Пишу, А. Базилевский, Стихи) 
(...) у маргаритки бывает и меньше ста лепестков (...) (Пишу, О. Басий, Спешите...)

(...) za to że róże śmieją się kolcami (...) Bóg zapłać (Za wiosnę, Zaufałem...)

(...) за то что розы смеются шипами (...) спасибо (За весну, Х. Сурта, Стихи)

Autor przedstawia bogatą kolorystykę kwiatów: bodziszki są niebieskie, najwięcej jest kwiatów białych, np.:

(...) a przecież białych kwiatów najwięcej na świecie / dopiero po nich żółte a potem czerwone (...) (Skąd przyszło, Zaufałem...)

(...) но белых цветов гораздо больше на свете / затем идут желтые а красных еще меньше (...) (Откуда пришло, О. Басий, Стихи)

(...) smutna łąka w sierpniu od bodziszków niebieska (...) (Wszystko smutne, Zaufałem...)

(...) печальная поляна в августе от гераней вся голубая (...) (Bce neчальное, Н. Астафьева, Стихи)

Twardowski wskazuje na funkcje, jakie pełnią kwiaty w życiu człowieka: chryzantemy najczęściej składane są na grobach zmarłych, szałwia uśmierza ból zębów, np.:

(...) Zosiu, coś wcześnie zmarła, aby nóżki krzywe - / szybko okryć żałobnym cieniem chryzantemy (...) (Do moich uczniów, Zaufałem...)

(...) и Зося, что так рано умерла, бедняжка, / чтоб ножек кривизну скрыть в белых хризантемах (...) (Моим ученикам, А. Нехай, Просьба)

(...) szałwio co umierasz i do nieba idziesz byle nas zęby nie bolały (...) (Owce między wilki, Zaufałem...)

(...) шалфей умирающий в небо идущий только б зубы у нас не болели (...) (Овць среди волков, А. Базилевский, Стихи)

c) Obraz roślin ozdobnych i zielnych

Kolejną podgrupę stanowią nazwy roślin, które pełnią przede wszystkim funkcję użytkową. Są to rośliny zielne, m.in.: kminek, niezapominajka, ptasi rdest, rumianek. Należą do nich gatunki dziko rosnacee, jak i wyhodowane z nich odmiany uprawne, które, z uwagi na zawartość substancji czynnych, znalazły zastosowanie w lecznictwie. W znaczeniu określeń tej 
grupy roślin jest wyeksponowany przede wszystkim ich walor funkcjonalny. Niemniej jednak dla księdza Jana ważne były także inne aspekty ziół, m.in. ich wygląd, zapach, miejsce rośnięcia. Stąd też w tekstach wierszy pojawiają się nazwy roślin pełniących jednocześnie funkcje ozdobne i lecznicze, m.in.: len, przebiśnieg, rzęsa wodna, wilcza jagoda. Poeta opisuje ich wygląd: leśny zawilec / najmniejszy i nieostatni, żólty żarnowiec znad morza, czerwona smółke jak lep na owady, przylaszczkę która z różowej staje sie niebieska, bławatek jak wianek / nieustanny i krótki, storczyk jak przystojnego pajaka, gotyckie rdzawe szczawie, polodowcowy mały siódmaczek, podaje czas kwitnienia: wiosenna firletke, mówi o walorach prozdrowotnych: jaskółcze ziele co leczy kurzajki, ale najważniejsze jest, że poszczególne rośliny swoją różnorodnością świadczą o potędze Boga, np.:

(...) I tylko w szczerym polu / w oddechu zioła / na klęczkach podziwiając zaspy nieba / można jeszcze odnaleźć Ciszę (***, Zaufałem...)

(...) И только в чистом поле / в дыхании трав / на коленях любуясь сугробами неба / можно еще отыскать Тишину (***, А. Базилевский, Сделано в Польше)

(...) smutna szałwia inaczej czerwona (...) (Wszystko smutne, Zaufałem...)

(...) печальный шалфей шарлахово-красный (...) (Все печальное, Н. Астафьева, Стихи)

(...) za dziwaczka co zakwita kiedy leje (...) Bóg zapłać ( $Z$ a wiosne, Zaufałem...)

(...) за ночецвет что под дождем зацветает (...) спасибо (За весну, Х. Сурта, Стихи)

Dziękuję Ci że (...) bladożółta psia trawka / (...) brunatnofioletowa wilcza jagoda (...) (Podziękowanie, Zaufałem...)

Спасибо тебе за то что (...) бледно-желты поганки / (..) красавка фиолетовая с коричневым оттенком (...) (Благодарение, А. Нехай, Просьба)

Спасибо Тебе за то что (...) бледно-желта собачья травка / (...) фиолетово-бурая ягода волчья (...) (Благодарность, М. Осмоловская, Польская поэзия...)

(...) choćbyś nie chciał stać $\mathrm{w}$ miejscu tylko się śpieszył / jak nagietki co kwitną przed dziesiątą rano (...) (Wszystko co dawne, Zaufałem...)

(...) хотя ты и не хотел бы замереть на месте а только спешил / как ноготки которые цветут до десяти утра (...) (Все давнее, Х. Сурта, Стихи) 
(...) potem wrzos optymista / bo zakwita ostatni / gotów był dać nam ślub (...) (To nieprawda że szczęście, Zaufałem...)

(...) потом безунывный вереск / он ведь цветет последним / готов был нас обручить (...) (Это неправда что счастье, А. Нехай, Просьба)

Twardowski wykorzystuje w swoich utworach niektóre znaczenia symboliczne roślin: głóg - bliskość, stałość związku; niezapominajka - wieczna pamięć; mak - przelotność, drobiazg; wrzos - podziw, samotność, harmonia z otoczeniem, przezwyciężanie zła; wierzba - łzy, żal; kalina - intensywne uczucia; konwalia - delikatność, nieśmiałość, ukojenie. W analizowanych wierszach niezapominajka oznacza pamięć, mak - prostotę, konwalia - samotność, np.:

(...) głogi tak bardzo bliskie że siebie nie znają (...) (Co prosi o miłość, Zaufałem...)

(...) шипы настолько близки что даже и не знакомы (...) (Просящий о любви, И. Баранов, Стихи)

(...) za to że miałeś oczy większe od wojny / jak polegli w rowie z niezapominajką (...) (Dlatego, Zaufałem...)

(...) за то что Твои глаза были огромней войны / как у лежащих в окопе с незабудками (...) (Потому, О. Басий, Стихи)

Już myślałem, że Ciebie wielkiego zobaczę, / a Tyś mignął mi w polu jak najprostszy mak (...) (***, Zaufałem...)

Я-то думал увидеть Тебя в слепящем величье, однако / Ты, словно скромный мак, в поле мелькнул предо мной (...) (***, А. Базилевский, Спешите...)

Trawa czuła łaskocze łydki / (...) uwodzi kalina (...) (Nie tylko, Zaufałem...) Трава ласкает икры / (...) (Не только, А. Базилевский, Польская поэзия...)

(...) konwalie pierwsze z brzegu bliskie więc samotne (...) (Drzewa niewierzace, Zaufałem...)

(...) ландыш что близки мне стало быть одиноки (...) (Hе веруют деревья, Н. Астафьева, Стихи)

Przedstawione utwory pokazują, jak ważny dla Twardowskiego jest świat przyrody. Zainteresowania botaniczne wyprowadzają poetę poza ograniczony świat ludzki. Przez całe życie ważne dla księdza Jana było ubóstwo franciszkańskie, które spowodowało, że niejednokrotnie poeta porzuca język na rzecz milczącej adoracji stworzenia. Opisywane w utworach rośliny mają podstawową cechę ontologiczną: po prostu SĄ. 


\section{Techniki translacyjne $\mathrm{w}$ tłumaczeniu poezji}

\section{a) Przekład dosłowny}

Drugim zadaniem, postawionym w artykule, jest pokazanie sposobów, wedle których tłumacze przenosili obrazy roślin na grunt języka rosyjskiego. Zostanie przeprowadzona prezentacja sposobu tłumaczenia oraz transformacji przekładowych - leksykalnych, gramatycznych, składniowych - zastosowanych przez tłumaczy na drodze porównania jednostek tekstu oryginalnego i docelowego. W badanym materiale większość jednostek tłumaczeniowych została oddana w języku rosyjskim za pomocą tłumaczenia dosłownego, np.:

Szukasz prawdy ale nie tajemnic / liścia bez drzewa / wiedzy a nie zdziwienia (...) (Szukasz, Zaufałem...)

Ты ищешь истину но не тайн / листья без дерева / знания но не удивления (...) (Тьл ищешь, Х. Сурта, Стихи)

Po wiersz tak prosty że każdy zrozumie / po krzyżyk zwykły wystrugany z drzewa (...) (Do nieba, Zaufałem...)

За стихом настолько простым чтобы понял любой / за крестиком обыкновенным вырезанным из дерева (...) (На небо, И. Баранов, Спешите...)

Liść porzeczki co zmienia barwę na deszczu / sowa co ma oczy żółte z białymi brwiami / (...) anioł co już nie strzeże bo na grzech za późno / nie denerwują patrzą zwyczajnie / jak Niewidzialny chodzi koło mnie (Liść, Zaufałem...)

Лист смородины меняющий цвет под дождем / сова у которой желтые глаза и белые брови / (..) ангел что не хранит ведь как на грех уже поздно / они не нервничают просто смотрят / как Невидимый ходит рядом со мной (Лист, О. Басий, Стихи)

Święty Janie od Krzyża, kiedy pełnia lata (...) / rzuć mi malwę i nazwij Janem od Biedronki (Modlitwa do świętego Jana od Krzyża, Zaufałem...)

Святой Иоанн Креста, когда разгар лета (...) / брось мне мальву и назови Яном Божьей Коровки (Молитва святому Иоанну Креста, И. Баранов, Стихи)

Szkoda / dla jednej tylko osoby (...) / buków bo najchłodniej przy nich wśród upału (...) (Przyrost ludności, Zaufałem...)

Жалко / для одного человека (...) / буков возле которых в жару хранится прохлада (...) (Прирост населения, О. Басий, Стихи)

Nawet by nie wiedziano (...) / że biały dziwaczek zakwita kiedy deszcz pada (...) / że wierzba w fujarce smutna przy krowach wesoła (...) (Gdyby, Zaufałem...)

Никто не знал бы (...) / что белый ночецвет расцветает во время дождя (...) / а ива плачет в свирели но возле коров веселеет (...) (Ecли бь, А. Базилевский, Спешите...) 


\section{b) Transformacje gramatyczne}

W analizowanych przekładach występuje duża grupa wyrazów i związków wyrazowych, które zostały przetłumaczone na język rosyjski w sposób dosłowny z punktu widzenia semantyki. W procesie ich translacji zastosowano transformacje gramatyczne. Tłumacze wykorzystali następujące sposoby przekładu:

- zmiana liczby (rzeczownik lub związek wyrazowy: przymiotnik + rzeczownik w liczbie pojedynczej w języku polskim // rzeczownik w liczbie mnogiej w języku rosyjskim lub odwrotnie), np.:

(...) rozchodzą się jak w śmiechu porzucone kwiaty (...) (Bliscy i oddaleni, Zaufałem...)

(...) расходятся как в смехе брошенный цветок (...) (Близкие и отдаленньее, А. Нехай, Просьба)

(...) żuk zielenieje wśród traw / by śmierć nie dosięgła (...) (***, Zaufałem...) (...) жук зеленеет в траве / чтобы смерть не настигла (...) (***, А. Базилевский, Стихи)

Zaufałem drodze (...) / takiej nie w porę jak w listopadzie spóźnione buraki (...) (Zaufatem drodze, Zaufałem...)

Я доверился дороге (...) / такой неуместной как поздняя ноябрьская свекла (...) (Я доверился дороге, Х. Сурта, Стихи)

(...) Zgasł promyk jasnej chwały / i usechł liść wawrzynu (...) (Skarga, Zaufałem...)

(...) Луч славы погас - и вот / листья лавра увяли (...) (Жалоба, А. Базилевский, Спешите...)

(...) Zosiu, coś wcześnie zmarła, aby nóżki krzywe - / szybko okryć żałobnym cieniem chryzantemy (...) (Do moich uczniów, Zaufałem...)

(...) и Зося, что так рано умерла, бедняжка, / чтоб ножек кривизну скрыть в белых хризантемах (...) (Моим ученикам, А. Нехай, Просьба)

- manipulacja skalą (zamiana formy podstawowej rzeczownika formą deminutywną), np.:

(...) ogórki jak wiadomo rosną tylko nocą (...) (Wiersz z dedykacja, Zaufałem...)

(...) огурчики известно растут лишь в час ночной (...) (Стихотворение с посвящением, Н. Астафьева, Польские поэты...) 
Wobec bólu (...) / jak niemoralny kościół $\mathbf{z}$ eleganckim bukietem na ołtarzu (...) (Wobec bólu, Zaufałem...)

На фоне боли (...) / как аморальна церковь с изящным букетиком на алтаре (...) (На фоне боли, А. Базилевский, Стихи)

- zmiana kolejności wyrazów w związku wyrazowym (przymiotnik + rzeczownik w języku polskim zamieniony konstrukcją: rzeczownik + przymiotnik w jezzyku rosyjskim lub odwrotnie), np.:

(...) święta cebula krewna zdechłej lilii (...) ( Wiersz z dedykacja, Zaufałem...)

(...) родственница лилии луковица святая (...) (Cтихотворение с посвящением, Н. Астафьева, Польские поэты...)

(...) olcha czarna liście porzuca zielone (...) (Pisze, Zaufałem...)

(...) черная ольха зеленые листья роняет (...) (Пишу, А. Базилевский, Стихи)

c) Transformacje leksykalne

Pozostałe obrazy roślin, przedstawione przez Jana Twardowskiego, zostały przetłumaczone na język rosyjski z zastosowaniem przekształceń leksykalnych. Do analizy dwutekstów zostanie wykorzystany układ strategiczny zaprezentowany przez Jakowa Rieckiera [1974], który wymienia siedem typów przekształceń. Są to: dyferencjacja znaczeń (дифференциация значений), konkretyzacja znaczeń (конкретизация значений), generalizacja znaczeń (генерализация значений), „rozwinięcie logiczne” (смысловое развитие), przekład antonimiczny (антонимический перевод), „przekształcenie kompleksowe (całościowe)” (целостное преобразование) oraz kompensacja (компенсация потерь в процессе перевода). W analizowanym materiale nie znalazły odzwierciedlenia dwie z powyższych technik, tzn. dyferencjacja oraz przekład antonimiczny. Pozostałe techniki mają swoje potwierdzenie w badanych dwutekstach wierszy Jana Twardowskiego. Oto przykłady zastosowania poszczególnych transformacji leksykalnych:

\section{- Konkretyzacja}

(...) Tobie derkacz w zbożu Tobie zając w polu (...) (Więcej, Zaufałem...)

(...) Тебе деркач во ржи Тебе зайчишка в поле (...) (Все более, А. Нехай, Просьба)

Daj odejść (...) / od rękawiczek rozdających kwiaty (...) (Odejść, Zaufałem...) 
Дай уйти (...) / от перчаток раздающих розы (...) (Уйти, С. Аверинцев, Стихи)

(...) smutna szałwia inaczej czerwona (...) (Wszystko smutne, Zaufałem...)

(...) печальный шалфей шарлахово-красный (...) (Все печальное, Стихи)

\section{- Generalizacja}

(...) stokrotka ma czasem płatków dziewięćdziesiąt osiem (...) (Piszę, Zaufałem...)

(...) у маргаритки бывает и меньше ста лепестков (...) (Пишу, О. Басий, Спешите...)

Więc to Ciebie szukają (...) / gdy chcą oddawać wszystko umierać dla kogoś / maciejkę czułą w nocy pieścić na pamiątkę (...) (Więc to Ciebie szukaja, Zaufałem...)

Так это Тебя они ищут (...) / когда хотят все отдать умереть ради кого-то / ночью гладить нежный левкой взятый на память (...) (Taк это Тебя они ищут, А. Базилевский, Спешите...)

\section{- Rozwinięcie logiczne}

(...) żale jak byliny kwiaty zimnotrwałe (...) (To nieprawdziwe, Zaufałem...) (...) многолетней тоски зимостойкие всходы (...) (Все неладное, А. Гелескул, Польская поэзия...)

Szkoda / dla jednej tylko osoby / (...) buków bo najchłodniej przy nich wśród upału (...) (Przyrost ludności, Zaufałem...)

Жалко / для одного человека / (...) буков возле которых в жару хранится прохлада (...) (Прирост населения, О. Басий, Стихи)

Быбы жаль / для одного человека / (...) буков что дают прохладу в зной (...) (Прирост населения, Н. Астафьева, Польские поэты...)

\section{- Przekształcenie kompleksowe}

(...) Piękne są góry i lasy / i róże zawsze ciekawe / lecz z wszystkich cudów natury / jedynie poważam trawę (...) (***, Zaufałem...)

(...) Прекрасны леса и горы / и розы красой пленяют / но из чудес природы / мне ближе трава простая (...) (***, А. Базилевский, Спешите...)

Dziękuję Ci że (...) / bladożółta psia trawka (...) (Podziękowanie, Zaufałem...) Спасибо тебе за то что (...) / бледно-желты поганки (...) (Благодарение, А. Нехай, Просьба) 
(...) być zbitym na kwasne jabłko (Wiem, Zaufałem...)

(...) быть избитым до полусмерти (Знаю, А. Базилевский, Стихи)

Brzozo nazbyt wieśniacza aby rosnąć w mieście (...) (Drzewa, Zaufałem...) Береза слишком дикая чтобы расти в городе (...) (Деревья, А. Базилевский, Польская поэзия...)

(...) milczą za gęsto rosnące topole / dwie obok siebie niespokojne rzeki (...) (We dwoje, Zaufałem...)

(...) молчат все тополя в рядочке тесном / двух беспокойных рек одно теченье (...) (Вдвоем, А. Нехай, Просьба)

Że właśnie taki dzień, że właśnie takie dnie / że wrogów pełna sień, że cierń się czarny pnie - / że tuż za furtą kwiat na piękne rzęsy spadł / (...) Że właśnie taki dzień, że właśnie takie dnie / zmęczenia w oczach cień, spokoju trochę $\mathrm{w}$ śnie - / że wiśni pełen sad, że wolna droga w świat (...) (***, Zaufałem...)

И только этот день, близнец иного дня / и вражеская чернь, и терние огня - / цветок. Слетевший в ад без воли, наузад / (...) И только этот день, близнец иного дня / изнеможенья тень, дремотная броня, / и вишенье, и сад, и вольный путь назад (...) $(* * *$, Г. Ефремов, Польская поэзия...)

\section{- Kompensacja}

(...) w zdartą korę czeremchy co pachnie migdałem (...) (Poczekaj, Zaufałem...) (...) что кора черемухи пахнет миндалем (...) (Погоди, А. Базилевский, Польская поэзия...)

(...) maciejkę czułą w nocy pieścić na pamiątkę (...) (Więc to Ciebie szukaja, Zaufałem...)

(...) ночью гладить нежный левкой взятый на память (...) (Taк это Тебя они ищут, А. Базилевский, Спешите...)

Otaczająca nas przyroda należy do uniwersaliów kosmogenicznych, stąd też podjęta tu tematyka sama $\mathrm{w}$ sobie nie stanowiła problemu w procesie tłumaczenia. Polacy i Rosjanie żyją w zbliżonej strefie klimatycznej, więc opisane w wierszach gatunki flory nie są im obce. Tłumacze twierdzą jednak, że o Twardowskim chce się mówić przede wszystkim jego słowami, w procesie przekładu zgłębiać i chłonąć jego myśli i uczucia [por. Baranow 2009, 5]. Trudnością dla wielu z nich była zapewne dbałość poety o każdy szczegól, jego bardzo bogata wiedza przyrodnicza zawarta w poszczególnych utworach. Leksyka związana ze światem przyrody wymagała częstszego posiłkowania się materiałem słownikowym. Tłumacze podczas pracy nad przekładem analizowanej poezji poszerzają swoją wiedzę przyrodniczą, uczą się od 
Twardowskiego jego pojmowania świata i swoistego odcienia języka, jakim opisuje świat natury.

\section{Językowy obraz roślin a przekład}

Już pobieżne porównawcze zestawienie polskich i rosyjskich tekstów wierszy księdza Jana, obrazujących świat roślin, pokazuje, że są to, w znakomitej większości, obrazy wspólne. Tłumacze, opisując zastane w oryginale elementy przyrody, posłużyli się rosyjskimi ekwiwalentami odnośnych nazw roślin. W tekstach przekładu dominują te same, co w oryginale barwy, emocje towarzyszące przedstawianiu świata przyrody tak bliskiego każdemu człowiekowi, w szczególności, autorowi wierszy. Twardowski określa przyrodę poprzez stosowanie w poszczególnych utworach konkretnych nazw rodzajowych lub gatunkowych.

W zdecydowanej większości wypadków tłumacze stosują przekład dosłowny, np.: akacja- акаuия; wierzba-uвa; brzozy - березьь. Zdarzają się także sytuacje, kiedy następuje zmiana konstrukcji gramatycznej poprzez zastąpienie słowa wyrażeniem i odwrotnie, np.: jaskółcze ziele- uucmomeл; przylaszczka - болотная фиалка; zmiana liczby, np.: buraki - свекла. Роeta, konstruując opisy działań elementów natury, używa różnych czasów, z przewagą teraźniejszego, różnych aspektów, form osobowych, imiesłowów. Większość stanów i czynności została przekazana w języku przekładu bez żadnych zmian, np.: leszczyna rodzi swój orzech - лещина рождает лесной орех; róże śmieja się kolcami-poзы смеются шипами; jaskółcze ziele leczy kurzajki-чистотел лечит бородавки; nagietki co kwitna przed dziesiata rапо - ноготки которье иветут до десяти утра. Pojawiają się także różnego typu przekształcenia form czasownika zastosowane przez tłumaczy, np. zmiana aspektu: brzоzy trzероса - расшумелись березы; zamiana formy osobowej imiesłowem: jesionie co tracisz liście - ясень теряющий листья; szalwio co uтierasz - шалфей умирающий. Twardowski w swoich wierszach stosuje także różne grupy nominalne, tworząc często oryginalne połączenia rzeczownika z przymiotnikiem lub dwóch rzeczowników. Cechą charakterystyczną jego poezji jest również manipulacja skalą, np.: ogórki - oгypuu$\kappa u$. W badanych obrazach natury te środki językowe pojawiały się jednak sporadycznie. Zarówno grupy nominalne, jak też pozostałe środki wykorzystane przez poetę najczęściej były tłumaczone na język rosyjski w sposób dosłowny, np.: dyskretny grabie - нежный граб; z pomaturalnych czereśni - от выпускных черешен; sтитпа taka - печальная поляна; тосzоредыпа pietruszka - мочегонная петрушка. Zdarzają się przykłady zmiany szy- 
ku wyrażeń, opuszczeń, dyferencjacji lub zmiany znaczeń, zamiany części mowy, np.: gluchy odgłos taki- отголосок луга негромкий; najprostszy mak - скромный мак; róże zawsze ciekawe-poзы красой пленяют; wrzos optymista - безуньвныий вереск.

Przedstawione powyżej przykłady pokazują, że najczęściej tłumacze stosowali dosłowny przekład jednostek leksykalnych. Zdarzają się jednak wypadki, gdzie leksemy opisujące naturę, wyekscerpowane z tekstu oryginalnego, zostały decyzją tłumaczy zastąpione zupełnie innymi (psia trawka - поганки; przylaszczki- подснежники), nр.:

Dziękuję Ci że (...) bladożółta psia trawka / brunatnofioletowa wilcza jagoda (...) (Podziękowanie, Zaufałem...)

Спасибо Тебе за то что (...) бледно-желты поганки / красавка фиолетовая (...) (Благодарение, А. Нехай, Просьба)

Спасибо Тебе за то что (...) бледно-желта собачья травка / (...) фиолетово-бурая ягода волчья (...) (Благодарность, М. Осмоловская, Польская поэзия...)

(...) więc czasem wzruszenie jak szczęście przylaszczek / co się od razu na wiosnę kochają (...) (Co prosi o miłość, Zaufałem...)

(...) поэтому иногда волненье как счастье подснежников / любящих с приходом весны (...) (Просящий о любви, И. Баранов, Стихи)

Bywa także, że nazwy użyte przez autora w ogóle nie pojawiają się w tekstach przekładu (jabłko). Następuje opuszczenie lub zamiana danego wyrazu lub stałego zwrotu innym zwrotem, np.:

(...) być zbitym na kwaśne jabłko (...) (Wiem, Zaufałem...)

(...) быть избитым до полусмерти (...) (Знаю, А. Bazilevskij, Stihi).

Przeanalizowany materiał pokazuje, że przyroda jest ważnym tematem w twórczości księdza Jana Twardowskiego. Poeta zachował w sobie zdolność niesłychanie bliskiego obcowania z przyrodą. Na jej temat potrafi pisać „Z wnikliwością znawcy i pasją urzeczonego" [Smaszcz 1993, 364]. Idiolektalny językowy obraz świata, namalowany przez Jana Twardowskiego, zawiera charakterystyczne dla poety sposoby konstruowania sceny. Są nimi: grupy nominalne (sposoby określania zjawisk, cech, atrybutów, definicje poetyckie), grupy werbalne (opisy działań, stanów), szyk wyrazów, używanie czasów gramatycznych, określoność - nieokreśloność, manipulacja skalą (zdrobnienia, zgrubienia), metaforyczność, porównania i wiele innych. Te bardzo szczegółowe, poetycko namalowane obrazy, zostały odzwierciedlone przez tłumaczy na gruncie języka rosyjskiego. 


\section{Źródła}

„Gazeta Petersburska”, № 9 (91) 2008, переводы С. Свяцкого.

Twardowski J., 2007, Zaufatem drodze. Wiersze zebrane 1932-2006, Warszawa.

Астафьева Н., Британишский В., 2000, Польские поэты XX века. Антология, Ян Твардовский - перевод Н. Астафьевой, том 1, Санкт-Петербург.

Базилевский А., 2009, Сделано в Польше век XX, переводы А. Базилевского, Москва.

Войтыла К., Твардовский Я., Брандштеттер Р., 2012, Камень веры, составил и перевел с польского А. Базилевский, Москва.

Твардовский Я., 1993, [w:] Польская поэзия $X X$ век, под ред. А. Базилевского, переводы: М. Осмоловской, Г. Ефремова, А. Гелескула, А. Базилевского, С. Аверинцева, том 1, Москва.

Твардовский Я., 2006, Стихи, переводы: С. Аверинцева, Н. Астафьевой, А. Базилевского, И. Баранова, О. Басий, Х. Сурты, Москва.

Твардовский Я., 2009, Спешите ююбить людей, переводы: С. Аверинцева, Н. Астафьевой, А. Базилевского, И. Баранова, О. Басий, А. Гелескула, М. Осмоловской, Х. Сурты, Москва.

Твардовский Я., 2010, Просъба, перевод с польского А. Нехая, Санкт-Петербург.

\section{Literatura}

Forstner D., 1990, Świat symboliki chrześcijańskiej, Warszawa.

Karwala M., 1996, Metafizyka oczywistości (O poezji ks. Jana Twardowskiego), Kraków.

Kopaliński W., 2006, Stownik symboli, Warszawa.

Lurker M., 1989, Słownik obrazów i symboli biblijnych. Tłumaczył bp Kazimierz Romaniuk, Poznań.

Piekarczyk D., 2004, Kwiaty we wspótczesnym językowym obrazie świata, Lublin.

Poeta i paradoksy. Rozmowa z Janem Twardowskim. Rozmawiał Marek Zieliński, 1981, „Nowe Książki”, nr 1.

Smaszcz W., 1993, Postowie, [w:] Twardowski J., Wiersze, Białystok, s. 355-382.

Sochoń J., 2007, „Czy można serce zdjać naprawde z krzyża?”. Wizja poezji wewnętrznie petnej księdza Jana Twardowskiego, [w:] A to co na krótko może być na zawsze... Pokłosie spotkania poświęconego pamięci księdza Jana Twardowskiego, pod red. E. Hoffmann-Piotrowskiej, J. Puzyniny, Warszawa, s. $31-44$.

Sulikowski A., 2007, Zielnik księdza Jana Twardowskiego, [w:] A to co na krótko może być na zawsze... Pokłosie spotkania poświęconego pamięci księdza Jana Twardowskiego, pod red. E. Hoffmann-Piotrowskiej, J. Puzyniny, Warszawa, s. $81-95$. 
Twardowski J., 2007, Budzić nadzieję. Abecadto dziewięćdziesięciolatka, Warszawa. Баранов И., 2009, [w:] Твардовский Я., Спешите любить людей, Москва, с. 3-5. Рецкер Я., 1974, Теория перевода и переводческая практика, Москва.

\title{
PANTHERA, ORCHID AND ALL OTHER WEEDS IN JAN TWARDOWSKI'S POEMS AND THEIR RUSSIAN TRANSLATIONS
}

\author{
S U M M A R Y
}

The subject of the study is a linguistic image of plants, taken from the poems of Father Twardowski, compared to his translation into Russian. One of the main features of Twardowski's poetry, regardless of the themes of the works, is the attitude to the sacred. The proposed analysis is based on a research model of cultural linguistics, referring to the cognitive paradigm, while taking into account the applied translation strategies and techniques. The lingual image of the plant is considered in two dimensions. As part of the monolingual analysis mentioned individual plants appearing in the texts examined, their symbolism and role in human life were presented. Conversely, the bilingual analysis showed what happens to the linguistic image of the world when it is transferred to another language, in this case Russian. 